\title{
Ethanol Extract of Carica papaya Leaf Can Increase Breast Milk in Lactating Rat
}

\author{
Yanti Herawati ${ }^{1,2 * \mathbb{D}}$, Umi Kalsum ${ }^{3}$, I Wayan Arsana Wiyasa ${ }^{4}$, Lelly Yuniarti ${ }^{5}$, Teguh Wahju Sardjono ${ }^{6}$ (D) \\ ${ }^{1}$ Midwifery Master Program, STIKES Dharma Husada, Bandung, Indonesia; ${ }^{2}$ Doctoral Program, Faculty of Medicine, Universitas \\ Brawijaya, Malang, Indonesia; ${ }^{3}$ Department of Pharmacology, Faculty of Medicine, Universitas Brawijaya, Malang, Indonesia; \\ ${ }^{4}$ Department of Obstetric and Gynecology, Saiful Anwar Hospital, Faculty of Medicine, Universitas Brawijaya, Malang, \\ Indonesia; ${ }^{5}$ Department of Biochemistry, Faculty of Medicine, Universitas Islam Bandung, Bandung, Indonesia; ${ }^{6}$ Department of \\ Parasitology, Faculty of Medicine, Universitas Brawijaya, Malang, Indonesia
}

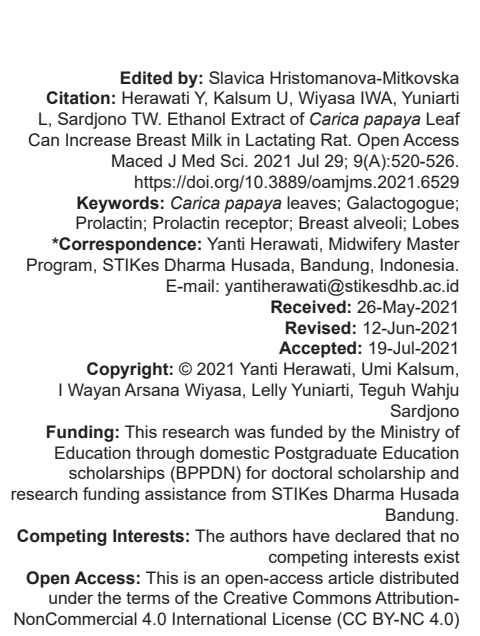

\section{Abstract}

BACKGROUND: Carica papaya leaves (C. papaya $L$ ) have been used empirically and traditionally as a galactogogue but their mechanism as galactogogue is still unknown.

AIM: This study aimed to analyze the effect of ethanol extract from papaya leaves on blood prolactin levels, prolactin receptor (prlr) gene expression, the number of breast alveoli and lobes of lactating rats.

METHODS: This in vivo true experimental study with a post-test control group design was conducted on 24 rats with the same lactating period. They were divided into four groups consisting of six rats each. The control group was given daily standard food, whereas the three treatment groups were, respectively, given additionally ethano extract of $0.95 \mathrm{mg}, 1.9 \mathrm{mg}$, and $3.8 \mathrm{mg} / 200 \mathrm{~g} \mathrm{BW} /$ day from day 1 to day 14 of lactation. On day 14 , all of the rats were sacrificed, blood prolactin levels were measured by ELISA, prlr gene expressions were measured using reverse transcription polymerase chain reaction, and numbers of breast alveoli and lobes were microscopically observed through staining histological specimens. A statistical analysis was carried out using one-way analysis of variance, Tukey's test, Games-Howell test, and path analysis at 95\% confidence level.

RESULTS: Levels of blood prolactin levels, prlr gene expression, the number of breast alveoli, and lobes of al treatment rat groups were significantly above those of the control group $(p<0.05)$. The increases of all parameters were consistent; the most effective dose was $1.9 \mathrm{mg} / 200 \mathrm{~g} \mathrm{BW}$.

CONCLUSIONS: The $C$. papaya leaf ethanol extract had a galactogogue effect on lactating rats by increasing blood prolactin levels, prir gene expression, and numbers number of breast alveoli and lobes.

\section{Introduction}

Breast milk has been commonly known as the best source of nutrition required for the growth and development of babies and children [1], [2], [3]. Breast milk is also a source of energy to increase immunity and intelligence; prevent babies from risk of allergies, reduce the risk of obesity, gastroenteritis, infection, asthma, and several types of cancer in children; and foster a psychological bond between mothers and babies [4], [5], [6]. For mothers, breastfeeding can reduce the risk of breast cancer and ovarian and endometrial cancer and accelerate the return of maternal weight to the state before pregnancy [7].

Prolactin is a polypeptide hormone that is responsible for lactation, breast development, and hundreds of other mechanisms required to maintain the lactation process, particularly in the growth and development of the mammary glands (mammogenesis), milk synthesis (lactogenesis) and maintenance of breast milk production (galactopoesis) [8], [9], [10]. During the lactation process, prolactin is needed to meet the nutritional components of breast milk. Prolactin can stimulate glucocorticoids in breast milk [11] proteins in mammary epithelial cells. It can also trigger the growth and development of alveolar cells [9]. Previous studies have indicated that alveolar cell culture added with prolactin, epidermal growth factor, and glucocorticoid can trigger the secretion of a $\beta$-casein signal. In addition, prolactin can also increase the absorption of several amino acids, glucose, and immunoglobulin $A$ from the intestinal tissue [12].

Prolactin activity begins when it binds to the prolactin receptor (prlr) located on the surface of the mammary epithelial cell membrane. It possibly induces prlr dimerization, thereby activating the Janus Kinase 2 (Jak2) signaling pathway. Jak2 is a transcription factor that can activate the expression of signal transducer and activator of transcription 5 (STAT5), which plays a role in controlling the differentiation process of the mammary gland ducts [13], [14]. 
Prlrs are glycoproteins consisting of 598 amino acid residues encoded by genes located on chromosome 5. Prlr is located on the surface of the mammary epithelial cell membrane, pituitary gland, ovary, uterus, liver, and kidneys [15] Apart from Jak2, prlr can be activated by ligand mediation through tyrosine kinase signaling pathways such as Fyn, Raf2, STAT, mitogen activated protein kinases, triphosphate inositol, and VAV [16].

Increased levels of prolactin can be influenced by several factors, such as breastfeeding frequency, experience, breast milk production, drug use, and galactogogue [8]. Delayed onset of lactogenesis II is defined as the increase in lactation during the first $72 \mathrm{~h}$ postpartum. Risk factors for this case include primiparity, cesarean section, high body mass index, and stress during labor or prolonged labor. Nursing mothers with low milk production can be given galactogogue therapy in herbal and pharmacological forms [17], given that the herbal galactogogue at the age of 1-2 weeks postpartum is effective in increasing prolactin serum and oxytocin serum levels in nursing mothers [18], [19]. Currently, herbal galactogogue is more widely used as alternative therapy to increase breast milk production.

Galactogogues are synthetic materials or plant molecules or substances that are used to induce, maintain, and increase breast milk production [20], [21]. Papaya leaves have been used by the community to increase breast milk production. Papaya leaves contain alkaloids including carpaine and pseudocarpaine, enzymes (papain, chymopapain, and cystatin), tocopherol, ascorbic acid, tannins, nicotinic acid, saponins, peonidin, chlorogenic acids, coumarin compounds, phenolic compounds (caffeic acid, p-coumaric acid and protocatechuic acid) as the main phytochemicals and flavonoids [22], [23]. Flavonoid level in Carica papaya leaves is $126 \mathrm{mg} / 100 \mathrm{~g}$, with quercetin and kaempferol as the main compounds [24]. Although, papaya leaves have been used to increase breast milk production, scientific evidence and an explanation for this increase have not been studied yet. This study aims to analyze the effect of papaya leaves ethanol extract on blood prolactin levels, prlr gene expression in mammary tissue, and an overview of the number of alveoli and the number of lobes of mammary tissue of lactating rats.

\section{Methods}

\section{Research method and subject}

This in vivo true experimental laboratory study with the post-test-only control group design was conducted using female Wistar rats obtained from the Laboratory of Animal Breeding Division, PT Biofarma,
Bandung, Indonesia. The research was carried out from September 2019 to September 2020 in several laboratories, namely the School of Life Sciences and Technology ITB, Anatomical Pathology Laboratory of Universitas Brawijaya, and Animal Physiology Laboratory and Central Laboratory of Universitas Padjadjaran. This research obtained research permission and was approved by the Research Ethics Commission of Universitas Padjadjaran Bandung (no. 1340/UN6.KEP/EC/2019).

\section{Experimental animals}

The samples of this study were 24 female Wistar rats (Rattus norvegicus) aged 12-14 weeks, with a body weight of 200-225 g. The rats were simultaneously paired mated within one night, after synchronization of the estrous cycle utilizing the natural phenomena, namely Leeboth pheromone and Whitten effect, so that they had the same period of lactation [25]. The lactating rats were then divided into four groups consisting of six rats each, the control group and groups D1, D2, and D3 as treatment groups. The control group was given daily ordinary food, while groups D1, D2, and D3 were, respectively, given the ethanol extract of papaya leaves with dose 1 (0.95 mg/200 g BW/day), dose 2 (1.9 mg/200 g BW/day), and dose 3 (3.8 mg/200 g BW/day), from day 1 to day 14 post delivery. The rats were then anesthetized, by taking blood through cardiac puncture for measurement of the blood prolactin level.

\section{C. papaya ethanol extract}

Papaya leaves (C. papaya L.) were obtained from Manoko (Lembang), West Java plantation. The extraction process of papaya leaves for the test material was determined at the School of Life Sciences and Technology, ITB, Bandung, West Java, according a previous study [26].

\section{Measurement of the prolactin level}

Serum was obtained from $3 \mathrm{~mL}$ of rat blood which was put into a tube and allowed to clot for $2 \mathrm{~h}$ at room temperature or overnight at $4^{\circ} \mathrm{C}$ and then centrifuged for $15 \mathrm{~min}$ at $1.000 \times \mathrm{g}$. Measurement of blood prolactin levels was carried out using ELISA, ELISA KIT Cusabio (\# CatCSB-E06881r).

\section{Measurement of prlr gene expression (prlr)}

Prlr gene expression was measured using Real Time polymerase chain reaction (PCR), which measures the prlr gene expression calculated using relative quantification by comparing the prir mRNA expression with the GAPDH housekeeping gene. The primary sequence of prlr gene used is forward 
5'-TGCCAGCCTCGTCTCATAG-3' and reverse 5'-GGCTTAACACCTTGACCTGGATACTC-3'. The primary sequence GAPDH used is forward GAPDH: 5'-TGCCAGCCTCGTCTCATAG-3' and reverse GAPDH: 5'-ACTGTGCCGTTGAACTTGC-3'. The examination procedure is according to Reagent (Onestep quantitative reverse transcription PCR (qRTPCR), Mytaq Bioline) and real-time PCR machine (PikoReal, Thermo Fisher Scientific). The number of cycles, temperature, and time are according to the previous optimization for each gene being examined. Reverse transcription was carried out at $45^{\circ} \mathrm{C}$ for $10 \mathrm{~min}$. Initial activation (holding stage) was carried out at $95^{\circ} \mathrm{C}$ for $2 \mathrm{~min}$ and 40 PCR cycles: (cycling stage) denaturation at $95^{\circ} \mathrm{C}$ for $5 \mathrm{~s}$. Annealing of prolactin was done at $59^{\circ} \mathrm{C}$ for $20 \mathrm{~s}, \mathrm{GAPDH}$ at $57^{\circ} \mathrm{C}$ for $20 \mathrm{~s}$, followed by a melt curve at $60^{\circ} \mathrm{C}-95^{\circ} \mathrm{C}$. The level of gene expression was calculated according to the $2^{-\Delta \Delta C T}$ method.

\section{tissue \\ Histological examination of mammary}

The numbers of alveoli and lobes of mammary tissue were examined and calculated through histological examination with hematoxylin-eosin $(\mathrm{HE})$ staining; then the numbers of alveoli glands and lobes at 400x magnification in five visual fields were read by two experts without prior knowledge of the group sample. Mammae samples were taken from the thoracic section.

\section{Data analysis}

The statistical methods used in this study include the Shapiro-Wilk test, one-way analysis of variance (ANOVA), Tukey's test, Games-Howell test, and path analysis at a 95\% confidence level ( $p \leq 0.05)$.

\section{Results}

\section{The effect of papaya leaves ethanol extract on prolactin levels}

After confirming that the data of blood prolactin levels were normally distributed ( $p>0.05$ - ShapiroWilk suitability test), we used one-way ANOVA to analyze their mean differences. The result indicated that levels of blood prolactin in all treatment groups were significantly higher than those in the control group, especially groups D2 and D3 ( $p<0.05)$, and the group with the highest levels was group D2, which had received a papaya leaf extract at a dose of $1.9 \mathrm{mg} / 200 \mathrm{~g}$ BW/day (Figure 1).

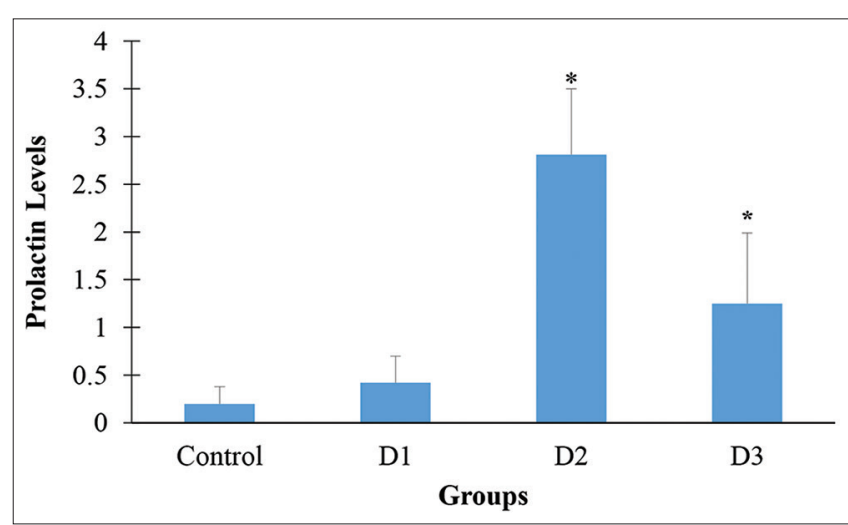

Figure 1: The Effect of Papaya Leaves Ethanol Extract on Prolactin Levels. $D 1=$ Dose of $0.95 \mathrm{mg} / 200 \mathrm{~g} \mathrm{BW} /$ day, $D 2=$ Dose of 1.9 $\mathrm{mg} / 200 \mathrm{~g} \mathrm{BW} /$ day, and D3 = Dose of $3.8 \mathrm{mg} / 200 \mathrm{~g} \mathrm{BW} / \mathrm{day}$. The data are presented as means \pm standard errors of means. ${ }^{*} p<0.05$ compared with the control group

\section{The effect of papaya leaves ethanol extract on prlr gene expression (prlr)}

The results of the one-way ANOVA test indicated addition of papaya leaf ethanol extract had an effect on the level of prir gene expression in the four groups $(p=0.000<\propto)$. Meanwhile, a post hoc analysis using the Games-Howell test indicated that the three treatment groups were significantly different from the control group, and the results indicated that the dose of papaya leaf ethanol extract that produced the highest prlr gene expression to increase the expression of the prlr gene in lactating rats was $1.9 \mathrm{mg} / 200 \mathrm{~g} \mathrm{BW} /$ day. The analysis of prlr gene expression for the four groups is presented in Figure 2.

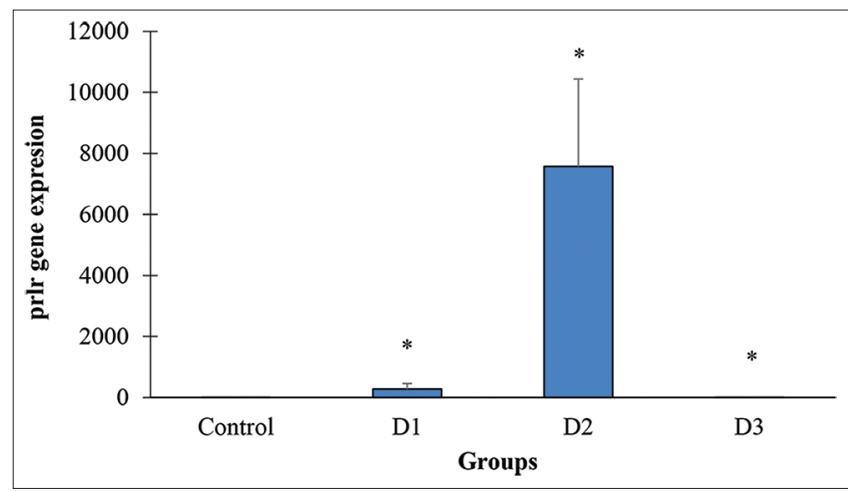

Figure 2: The Effect of Papaya Leaves Ethanol Extract on Prolactin Receptor Gene Expression. D1 = Dose of $0.95 \mathrm{mg} / 200 \mathrm{~g}$ BW/day, D2 = Dose of $1.9 \mathrm{mg} / 200 \mathrm{~g} \mathrm{BW} / \mathrm{day}$, and D3 = Dose of $3.8 \mathrm{mg} / 200 \mathrm{~g} \mathrm{BW} /$ day. The data are presented as means \pm standard errors of means. ${ }^{*} p<0.05$ compared with the control group

The effect of papaya leaves ethanol extract on the number of breast alveoli

The normality test was carried out using the Shapiro-Wilk test, and all data were normally distributed $(p>0.05)$. The one-way ANOVA test results 
indicated that there was a significant difference in the mean number of alveoli in the four groups $(p=0.000$ $<\propto)$. Tukey's test indicated that the dose of papaya leaf ethanol extract that produced the highest prlr gene expression to increase the expression of the prlr gene in lactating rats was $1.9 \mathrm{mg} / 200 \mathrm{~g} \mathrm{BW} /$ day to increase the number of alveoli in lactating rats. HE stain for breast alveoli is presented in Figure 3a. Analysis of the number of breast alveoli in the four groups is presented in Figure 3b.

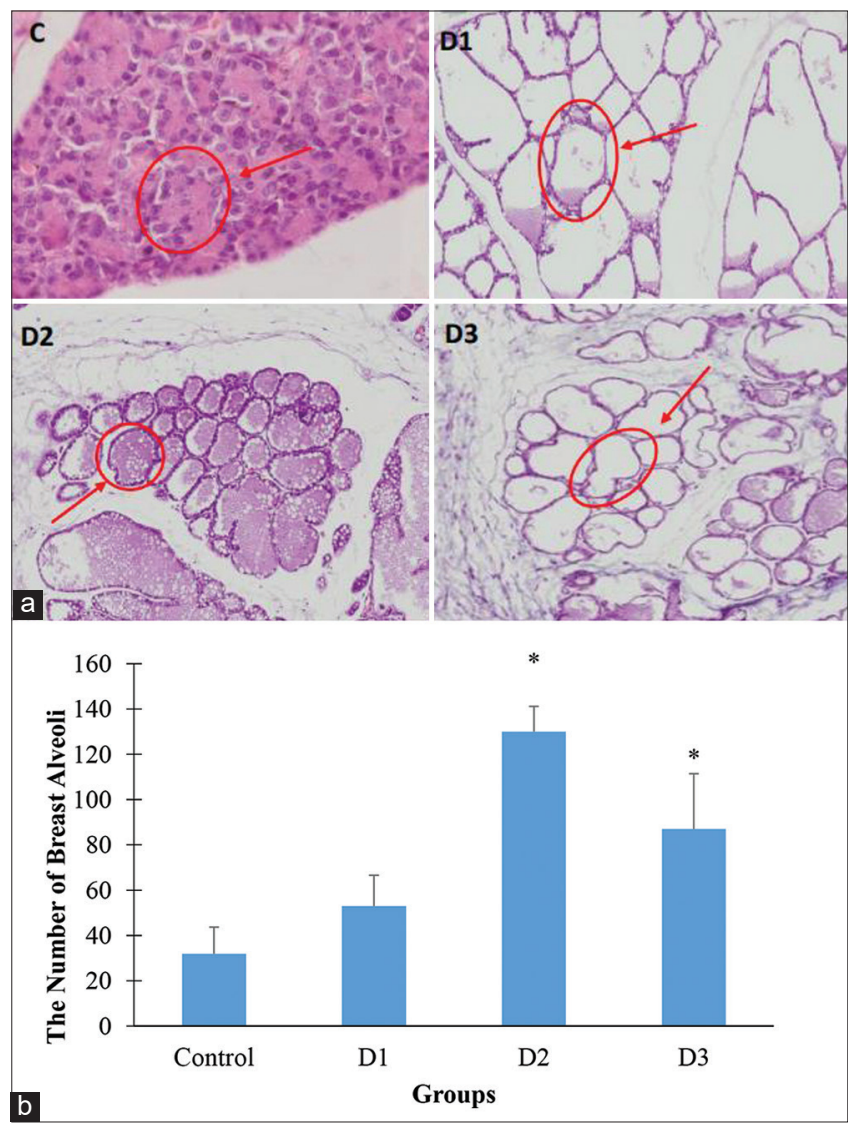

Figure 3: The Effect of Papaya Leaves Ethanol Extract on the number of breast alveoli. D1 = Dose of $0.95 \mathrm{mg} / 200 \mathrm{~g} \mathrm{BW/day,} \mathrm{D2} \mathrm{=} \mathrm{Dose}$ of $1.9 \mathrm{mg} / 200 \mathrm{~g} \mathrm{BW} /$ day, and D3 = Dose of $3.8 \mathrm{mg} / 200 \mathrm{~g} \mathrm{BW/day}$. (a) A number of breast alveoli of mammary tissue were stained with hematoxylin-eosin staining, with $400 \times$ magnification. (b) The data are presented as means \pm standard errors of means. ${ }^{*} p<0.05$ compared with the control group

The effect of papaya leaves ethanol extract on the number of lobes

The one-way ANOVA test results indicate that there is evidence that the mean number of lobes of the four observation samples $(p<0.000)$ in this test was carried out after the normality test using the ShapiroWilk test $(p>0.05)$. Tukey's test indicated that a dose of $1.9 \mathrm{mg} / 200 \mathrm{~g} \mathrm{BW} / \mathrm{h}$ was the highest dose that increased total protein levels in lactating rats. An HE stain for mammary lobes is presented in Figure 4a. Analysis of the number of lobes is presented in Figure $4 b$.

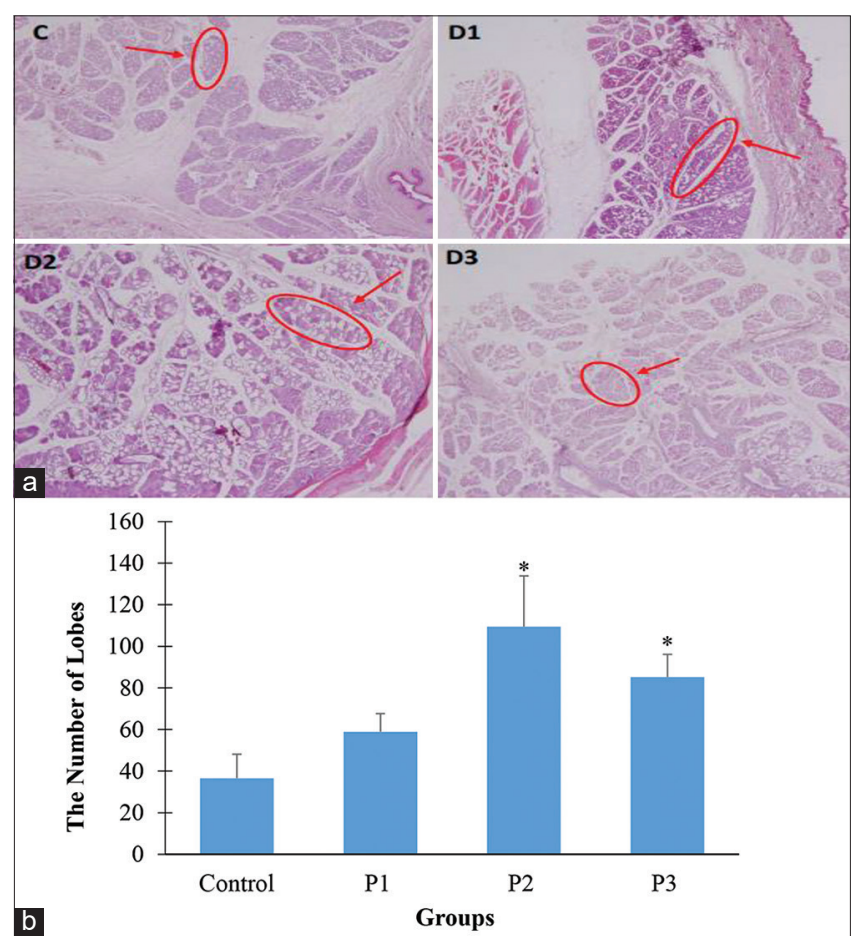

Figure 4: The Effect of Papaya Leaves Ethanol Extract on the number of breast lobes. $D 1=$ Dose of $0.95 \mathrm{mg} / 200 \mathrm{~g} \mathrm{BW} /$ day; $D 2=$ Dose of $1.9 \mathrm{mg} / 200 \mathrm{~g} B W /$ day; D3 = Dose of $3.8 \mathrm{mg} / 200 \mathrm{~d}$ BW/day. (a) A number of breast lobes of mammary tissue were stained with hematoxylin-eosin staining, with $400 \times$ magnification. (b) The data are presented as means \pm standard errors of means. ${ }^{*} p<0.05$ compared with the control group

Path analysis of prolactin levels, prlr gene expression (prlr), number of breast alveoli and number of lobes

The path analysis indicated that there was an effect between an ethanol extract from the papaya leaf on prolactin levels of $0.182(p=0.038)$, with a percentage of effect of $18.2 \%$. The effect between prolactin levels on prir gene expression of 0.752 $(p=0.000<\propto)$, with a percentage of effect of $75.2 \%$. The effect of prir gene expression on the number of breast alveoli is $0.554(p=0.000<\alpha)$, with the percentage of effect of $55.4 \%$. The effect of the number of breast alveoli on the number of lobes is $0.809(p=0.000<\propto)$, with the percentage of effect of $80.9 \%$. The effect of prolactin levels on the number of breast alveoli was $0.903(p=0.000<\propto)$, with the percentage of effect of $81.5 \%$. The effect of ethanol extract from the papaya leaf on the number of breast alveoli was $0.315(p=0.004)$, with a percentage of effect of $31.5 \%$, and the effect of ethanol extract from the papaya leaf on the number of lobes was 0.372 ( $p$ $=0.002$ ), with a percentage of effect of $37.2 \%$. Path analysis of prolactin levels, prlr gene expression, the number of mammary alveoli, and the number of lobes is presented in the Figure 5. 


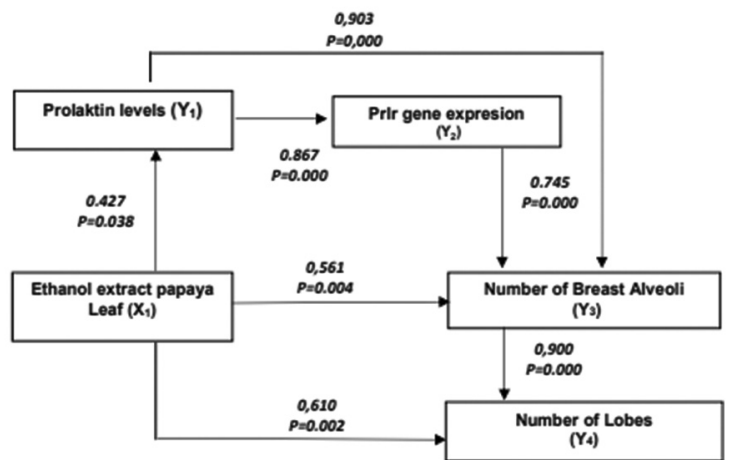

Figure 5: Path Analysis. The relationship model between ethano extract from the papaya leaf $\left(X_{1}\right)$, prolactin levels $(Y 1)$, prolactin receptor gene expression (Prlr) (Y2), alveoli in mammae (Y3), and mammae lobes (Y4)

\section{Discussion}

Research on papaya leaves as a galactogogue has not been conducted much; however, the papaya leaf extract has been used empirically as a nutraceutical because it contains nutritional components that can function as medicine. The flavonoids, glycosides, and vitamins in papaya leaves function as antioxidants; the minerals contained in these leaves can increase the mobility of the membrane transport system, and amino acids can function as protein precursors that can protect cells from free radicals [27].

The results of this study indicate that the ethanol extract of papaya leaves has a positive effect on increasing prolactin levels with the best concentration of $1.9 \mathrm{mg} / 200 \mathrm{~g} \mathrm{BW} /$ day. Based on previous research, certain phytochemical components can have a galactopoietic effect. Alkaloids can increase breast milk excretion; isoflavones can increase the excretion of breast milk protein, fat, and lactose; polyphenols can increase milk protein production; and tannins play a role in the protein digestion process [28]. A group of alkaloid compounds, flavonoids, and saponins can increase prolactin levels in plasma by inhibiting the estrogenprogesterone [29].

In this study, the D3 ethanol extract did not cause an increase in response to prolactin levels, presumably because $\mathrm{D} 2$ is the maximum compensatory response to the control group, also known as chemical conditioning hormesis, and can activate the target cell signaling pathway at the low dose [30]. In addition, each metabolite has a different bioavailability in the target organs, especially phytochemical compounds that have low bioavailability, so that even low doses can affect the metabolism [31]

A flavonoid is a secondary metabolite that is synthesized in almost every part of the plant in response to the environment. If it is consumed, the flavonoid acts as an immunomodulator, regulating gene expression, which affects the bioactivity and bioavailability of the metabolite and plays an important role in cellular interactions [32]. A flavonoid is a type of phytoestrogen, which is a derivative compound from natural (plant) materials that have the same structure and function as the estrogen in the body [33].

Papaya leaves contain alkaloid compounds such as carpaine and pseudocarpaine, enzymes (papain, chymopapain, and cystatin), tocopherol, ascorbic acid, tannins, nicotinic acid, saponins, peonidins, chlorogenic acid, the coumarin compound, and phenolic compounds as the main phytochemicals and flavonoids [34], [35], [36]. Quercetin as a phytoestrogen can stimulate prolactin production [37]. The content of metabolite compounds in papaya leaves is the same as that in three types of plants that are widely used as a galactogogue, namely Trigonella foenum-graecum (fenugreek), Asparagus racemosus (shatavari), and Moringa oleifera (malunggay) [38]. Asparagus contains large amounts of saponins [39]. Whereas Trigonella and Moringa contain flavonoids [40], [41].

The path analysis indicated that ethanol extract from a C. papaya leaf had an effect on prolactin levels, and $18.2 \%$ of prolactin levels were affected by extract ethanol from the C. papaya leaf. Prolactin levels had a strong effect on prlr gene expression, and $75.2 \%$ of prlr gene expression was affected by prolactin levels. Prolactin levels have a strong effect on the number of breast alveoli, and $81.5 \%$ of the number of breast alveoli are influenced by the level of prolactin. Prlr gene expression had a strong effect on the number of breast alveoli, and $55.4 \%$ of the alveoli were influenced by the expression of the prlr gene. The number of breast alveoli has a strong effect on the number of lobes, and as much as $80.9 \%$ of the number of lobes is influenced by the number of breast alveoli. Extract ethanol $C$. papaya leaf has an effect on the number of breast alveoli, and as much at $31.5 \%$ of the number of breast alveoli were influenced by extract ethanol C. papaya leaf. Extract ethanol C. papaya leaf has an effect on the number of lobes, and as much at $37.2 \%$ of the lobes were influenced by extract ethanol C. papaya leaf. These results are in accordance with the mechanism of the action of prolactin and prlr.

Prlr expression is strongly influenced by the level of prolactin in the blood [42], so that when the prolactin level increases, it will trigger an increase in prlr gene expression. At the same time, it increases the activity of proliferation and differentiation of mammary epithelial cells so that the number of alveoli and lobe cells increases and, in turn, leads to an increase in milk production [43], [44]. Overall, this study still has limitations because it does not carry out the isolation and analysis of active secondary metabolites so that the mechanism of the active substance cannot be certainly explained. 


\section{Conclusions}

The ethanol extract from papaya leaves has an effect as a galactogogue on the mechanism of increasing prolactin levels, prlr gene expression, the number of alveoli cells, and the number of lobes in mammary epithelial cells in lactating rats. Thus, this plant can be used as an alternative to a galactogogue herb to increase breast milk production.

\section{References}

1. Andreas NJ, Kampmann B, Le-Doare KM. Human breast milk: A review on its composition and bioactivity. Early Hum Dev. 2015;91(11):629-35. https://doi.org/10.1016/j. earlhumdev.2015.08.013

PMid:26375355

2. Feng $P$, Gao M, Burgher A, Zhou TH, Pramuk K. A nine-country study of the protein content and amino acid composition of mature human milk. Food Nutr Res. 2016;60(1):31042. https:// doi.org/10.3402/fnr.v60.31042

\section{PMid:27569428}

3. Lessen R, Kavanagh K. Position of the academy of nutrition and dietetics: Promoting and supporting breastfeeding. J Acad Nutr Diet. 2015;115(3):444-9. https://doi.org/10.1016/j. jand.2014.12.014

PMid:25721389

4. Cadwell K, Turner C. Manajemen Laktasi [Lactation Management]. Jakarta: EGC; 2011.

5. Ballard O, Morrow AL. Human milk composition: Nutrients and bioactive factors. Boreal Environ Res. 2013;60(1):49-74. PMid:23178060

6. Piwoz EG, Huffman SL. The impact of marketing of breastmilk substitutes on WHO-recommended breastfeeding practices. Food Nutr Bull. 2015;36(4):373-86. https://doi. org/10.1177/0379572115602174

\section{PMid:26314734}

7. Grzeskowiak LE, Wlodek ME, Geddes DT. What evidence do we have for pharmaceutical galactagogues in the treatment of lactation insufficiency?-A narrative review. Nutrients. 2019;11(5):974. https://doi.org/10.3390/nu11050974 PMid:31035376

8. Wambach K, Riordan J. Breastfeeding and Human Lactation. USA: Jones and Bartlett Publishers; 2005. p. 6-162

9. Lawrence RA, Lawrence RM. Breastfeeding: A Guide for the Medical Profession. Missouri, TX: Elsevier Publisher; 2011.

10. Al-Chalabi M, Bass AN, Alsalman I. Physiology, prolactin. In: Stat Pearls. Treasure Island, FL: Stat Pearls Publishing; 2021.

11. Nilsson L. Effects of Prolactin on Metabolism. Sweden: Department of Physiology, University of Gothenburg; 2009.

12. Kim YJ. Pivotal roles of prolactin and other hormones in lactogenesis and the nutritional composition of human milk. Clin Exp Pediatr. 2020;63(8):312-3. https://doi.org/10.3345/ cep.2020.00311 PMid:32746532

13. Radhakrishnan A, Raju R, Tuladhar N, Subbannayya T, Thomas $\mathrm{JK}$, Goel R, et al. A pathway map of prolactin signaling. J Cell Commun Signal. 2012;6(3):169-73.

\section{PMid:22684822}

14. Liu F, Pawliwec A, Feng Z, Yasruel Z, Lebrun JJ, Ali S. Prolactin/ Jak2 directs apical/basal polarization and luminal linage maturation of mammary epithelial cells through regulation of the Erk1/2 pathway. Stem Cell Res. 2015;15(2):376-83. https://doi. org/10.1016/j.scr.2015.08.001

PMid:26318719

15. Melmed S, Conn PM. Endocrinology: Basic and Clinica Principles. Totowa, NJ: Springer Science and Business Media; 2007.

16. Brooks CL. Molecular mechanisms of prolactin and its receptor Endocr Rev. 2012;33(4):504-25

PMid:22577091

17. Bazzano AN, Hofer R, Thibeau S, Gillispie V, Jacobs M, Theal KP. A review of herbal and pharmaceutical galactagogues for breast-feeding. Ochsner J. 2016;16(4):511-24. PMid:27999511

18. Srinivas R, Eagappan K, Sasikumar S. The effect of naturally formulated galactagogue mix on breast milk production, prolactin level and short-term catch-up of birth weight in the first week of life. Int J Health Sci Res. 2014;4(10):242-53.

19. Hill PD, Aldag JC, Demirtas H, Naeem V, Parker NP, Zinaman MJ et al. Association of serum prolactin and oxytocin with milk production in mothers of preterm and term infants. Biol Res Nurs. 2009;10(4):340-9. https://doi.org/10.1177/1099800409331394 PMid:19224938

20. ZuppaAA, Sindico P, Orchi C, Carducci C, Cardiello V, Romagnoli C et al. Safety and efficacy of galactogogues: Substances that induce, maintain and increase breast milk production. J Pharm Pharm Sci. 2010;13(2):162-74. https://doi.org/10.18433/j3ds3r PMid:20816003

21. Tabares FP, Jaramillo JV, Ruiz-Cortés ZT. Pharmacological overview of galactogogues. Vet Med Int. 2014;2014:602894 PMid:25254141

22. Seigler DS, Pauli GF, Nahrstedt A, Leen R. Cyanogenic allosides and glucosides from Passiflora edulis and Carica papaya. Phytochemistry. 2002;60(8):873-82. https://doi.org/10.1016/ s0031-9422(02)00170-x PMid: 12150815

23. Ikram EHK, Stanley R, Netzel M, Fanning K. Phytochemicals of papaya and its traditional health and culinary uses-a review. J Food Compos Anal. 2015;41:201-11. https://doi.org/10.1016/j. jfca.2015.02.010

24. Miean KH, Mohamed S. Flavonoid (myricetin, quercetin kaempferol, luteolin, and apigenin) content of edible tropical plants. J Agric Food Chem. 2001;49(6):3106-12. https://doi. org/10.1021/jf000892m

PMid: 11410016

25. Sardjono TW, Gondo HK, Nugraha RY, Putri AT, Effendy MC The use of natural phenomenon in obtaining pregnant rats and mice as experimental animals with the same gestational ages. J Trop Life Sci. 2019;9(3):229-35. https://doi.org/10.11594/ jtls.09.03.03

26. Zhang QW, Lin LG, Ye WC. Techniques for extraction and isolation of natural products: A comprehensive review. Chin Med. 2018;13(1):20.

PMid:29692864

27. Imaga NA, Gbenle GO, Okochi VI, Adenekan S, DuroEmmanuel T, Oyeniyi B, et al. Phytochemical and antioxidant nutrient constituents of Carica papaya and Parquetina nigrescens extracts. Sci Res Essays. 2010;5(16):2201-5.

28. Mohanty I, Senapati MR, Jena D, Behera PC Ethnoveterinary importance of herbal galactogogues-a review. Vet World. 2014;7(5):325-30. https://doi.org/10.14202/ vetworld.2014.325-330 
29. Yakubu MT, Akanji MA, Oladiji AT, Olatinwo AO, Adesokan AA, Yakubu MO, et al. Effect of Cnidoscolous aconitifolius (Miller) I. M. Johnston leaf extract on reproductive hormones of female rats. Iran J Reprod Med. 2008;6(3):149-55.

30. Calabrese EJ, Bachmann KA, Bailer AJ, Bolger PM, Borak J, Cai L, et al. Biological stress response terminology: Integrating the concepts of adaptive response and preconditioning stress within a hormetic dose-response framework. Toxicol Appl Pharmacol. 2007;222(1):122-8.

PMid: 17459441

31. Holst B, Williamson G. Nutrients and phytochemicals: From bioavailability to bioefficacy beyond antioxidants. Curr Opin Biotechnol. 2008;19(2):73-82. https://doi.org/10.1016/j. copbio.2008.03.003

PMid:18406129

32. Alseekh S, de Souza LP, Benina M, Fernie AR. The style and substance of plant flavonoid decoration; towards defining both structure and function. Phytochemistry. 2020;174:112347. https://doi.org/10.1016/j.phytochem.2020.112347 PMid:32203741

33. Salahshoor MR, Mohammadi MM, Roshankhah S, Jalili C. Effect of Falcaria vulgaris on milk production parameters in female rats' mammary glands. J Family Reprod Health. 2018;12(4):177-83. PMid:31239844

34. Canini A, Alesiani D, D'Arcangelo G, Tagliatesta P. Gas chromatography-mass spectrometry analysis of phenolic compounds from Carica papaya L. leaf. J Food Compos Anal. 2007;20(7):584-90. https://doi.org/10.1016/j.jfca.2007.03.009

35. Suresh K, Deepa P, Harisaranraj R, Vaira AV. Antimicrobial and phytochemical investigation of the leaves of Carica papaya L., Cynodon dactylon (L.) Pers., Euphorbia hirta L., Melia azedarach L. and Psidium guajava L. Ethnobot Leafl. 2008;12:1184-91.

36. Duke J. Phytochemical and Ethnobotanical Database; 2011. Available from: http//www.sun.ars-grin.gov:8080/npgspub/xsql/ duke/plantdisp.xsql?taxon=209. [Last accessed on 2017 Sep 05].

37. Lin M, Wang N, Yao B, Zhong Y, Lin Y, You T. Quercetin improves postpartum hypogalactia in milk-deficient mice via stimulating prolactin production in pituitary gland. Phytother Res. 2018;32(8):1511-20. https://doi.org/10.1002/ptr.6079 PMid:29671937

38. Haschke F, Haiden N, Thakkar SK. Nutritive and bioactive proteins in breastmilk. Ann Nutr Metab. 2017;69 Suppl 2:17-26. https://doi.org/10.1159/000452820

PMid:28103610

39. Alok S, Jain SK, Verma A, Kumar M, Mahor A, Sabharwal M Plant profile, phytochemistry and pharmacology of Asparagus racemosus (Shatavari): A review. Asian Pac J Trop Dis. 2013;3(3):242-51. https://doi.org/10.1016/ s2222-1808(13)60049-3

40. Badgujar SB, Patel VV, Bandivdekar AH. Foeniculum vulgare Mill: A review of its botany, phytochemistry, pharmacology, contemporary application, and toxicology. Biomed Res Int. 2014;2014:842674. https://doi.org/10.1155/2014/842674 PMid:25162032

41. Paikra BK, Dhongade HK, Gidwani B. Phytochemistry and pharmacology of Moringa oleifera Lam. J Pharmacopuncture. 2017;20(3):194-200. https://doi.org/10.3831/kpi.2017.20.022 PMid:30087795

42. Augustine RA, Kokay IC, Andrews ZB, Ladyman SR, Grattan DR. Quantitation of prolactin receptor mRNA in the maternal rat brain during pregnancy and lactation. $\mathrm{J}$ Mol Endocrinol. 2003;31(1):221-32. https://doi.org/10.1677/jme.0.0310221 PMid: 12914538

43. Gass S, Harris J, Ormandy C, Brisken C. Using gene expression arrays to elucidate transcriptional profiles underlying prolactin function. J Mammary Gland Biol Neoplasia. 2003;8(3):269-85. https://doi.org/10.1023/b: jomg.0000010029.85796.63 PMid:14973373

44. Gorvin CM. The prolactin receptor: Diverse and emerging roles in pathophysiology. J Clin Transl Endocrinol. 2015;2(3):85-91. PMid:29204371 